\title{
Protein degradation and optimum urea concentration in cereal-based diets for sheep
}

\author{
BY A. Z. MEHREZ* AND E. R. ØRSKOV \\ Rowett Research Institute, Bucksburn, Aberdeen AB2 $9 S B$
}

(Received 20 June 1977 - Accepted I 3 April 1978)

\begin{abstract}
1. Early-weaned lambs were used to estimate the concentration of urea required to give the maximum intake and utilization of maize or barley with either a high (HPB) or low (LPB) protein content.

2. Approximately the same concentration of urea $(7-11 \mathrm{~g}$ urea/ $\mathrm{kg}$ feed) was required for maximum intake and feed utilization of both HPB and LPB. With maize there was no increase in intake, live weight gain, digestion and feed conversion as a result of adding more than $7 \mathrm{~g}$ urea $/ \mathrm{kg}$.

3. The proportion of protein degraded in the rumen was estimated by the synthetic fibre bag technique to be $0.69,0.82$ and 0.54 for HPB, LPB and maize respectively. The similarity in concentration of urea required for the optimum utilization of LPB and HPB might be explained by differences in the extent of degradation of protein in the rumen, but the lower concentration of urea required for maize cannot be similarly explained.

4. From estimates of yield of microbial protein in the rumen, the extent of rumen fermentation and the measured extent of protein degradation, theoretical requirements for urea were calculated and compared with other predictions and with the experimentally determined values. For barley, predicted values agreed reasonably well with experimental ones, but for maize all values, including those derived by a new system adopted by the Agricultural Research Council (ARC) Working Party, were too high.
\end{abstract}

In the ruminant, amino acids (AA) absorbed from the small intestine are derived from two sources, namely microbial and undegraded dietary protein (Ørskov, 1970, 1977; Miller, 1973). It is important, therefore, to differentiate between both the microbial need for nitrogen and the host animal's need for protein (see Roy, Balch, Miller, Ørskov \& Smith, 1977).

Schelling \& Hatfield (1968) and Nimrick, Hatfield, Kaminski \& Owens (1970) attempted to assess the protein requirements of lambs by feeding them on a purified diet containing urea as the sole source of $\mathrm{N}$ thus ensuring that only microbial protein entered the abomasum from the rumen; in addition, they measured responses to postruminal infusion of individual AA. We attempted to do the same using a different basal diet, namely barley supplemented with urea. The concentration of urea required to satisfy the microbial need for $\mathrm{N}$ was predicted from results obtained in another experiment (Ørskov, Fraser \& McDonald, 1972), in which barley was supplemented with different levels of urea. It became apparent, however, that the minimum urea concentration required for maximal voluntary intake could not be accurately predicted from the results obtained with a different batch of barley.

The object of the present work was to investigate the optimum concentration of urea required to supplement three different cereal samples and to compare this with predictions based on estimates of the $\mathrm{N}$ requirements of rumen micro-organisms. Two barleys, one high and one low in protein, and maize, known to contain both starch and protein resistant to rumen fermentation (Ørskov, Fraser \& Kay, 1969) were chosen. In one set of experiments the voluntary feed intake, live weight gain and digestibility were determined, and in another, the disappearance of cereal proteins from synthetic fibre bags suspended in the rumen was measured (Mehrez \& Ørskov, 1977).

* Present address: Faculty of Agriculture, University of Mansoura, El-Mansoura, Egypt. 


\section{EXPERIMENTAL}

\section{Animals}

Expt I. Seventy-two Suffolk $\times$ (Finnish Landrace $\times$ Dorset Horn) lambs were used (twenty-four for each of three cereals). The lambs used for the trial with the high-protein barley (HPB) were all entire males, while the lambs for the trials with the low-protein barley (LPB) and maize each consisted of twelve entire males and twelve females. All the lambs were weaned at 4 weeks of age, and were allocated to treatments when they weighed 15-20 kg (5-7 weeks of age).

Expt 2. Three Cheviot castrated sheep were used. They were about 2 years old and weighed $40-45 \mathrm{~kg}$. Each was fitted with a rumen cannula (40 $\mathrm{mm}$ in diameter) at least 3 weeks before the experiment started.

\section{Design and treatment}

Expt I. Each group of twenty-four lambs was divided into blocks of four that were similar in body-weight and of the same sex. The four lambs of each block were then allocated at random to one of four dietary treatments.

Three cereals were offered ad lib. alone, or supplemented with one of three amounts of urea. The $\mathrm{N}$ and ash contents $(\mathrm{g} / \mathrm{kg}$ dry matter) of the basal diets were $21 \cdot 4$ and $39 \cdot 2$, I6.7 and 39.9 and 15.4 and 27.9 for HPB, LPB and maize diets respectively. The urea concentration was increased by increments of 6,7 and $8 \mathrm{~g} / \mathrm{kg}$ for the $\mathrm{HPB}$, maize and LPB diets respectively, using the absorption method described by Ørskov, Smart \& Mehrez (1974). Each diet was supplemented (g/kg) with I $_{2} \mathrm{CaCl}_{2}, 4 \mathrm{Na}_{2} \mathrm{SO}_{4}$ and $\mathrm{I} \cdot 25$ of a trace mineral and vitamin mixture. The ingredients of the trace mineral and vitamin mixture, and the procedure used for incorporation, were the same as described by Ørskov \& Grubb (1977). Samples of the diets for chemical analysis were collected at weekly intervals during the experimental period and were bulked for each diet. The experimental period for measurements of voluntary intake was 8 weeks, after which the digestibilities of dry matter (DM) and organic matter (OM) were measured together with $\mathrm{N}$ retention using three male lambs per treatment (i.e. three blocks for each cereal).

Expt 2. The synthetic fibre bag technique (Mehrez \& Orskov, 1977) was used to describe the disappearance of DM, N and starch of the HPB, LPB and maize used in Expt $I$.

The two barleys were rolled, and the maize was ground before incubation. The samples were examined closely to ensure that they contained no whole grains (Mehrez \& Ørskov, I977).

\section{Feeding and management}

Expt I. The lambs were kept in individual pens and bedded with sawdust. Fresh water was available at all times. The amount of uneaten feed was recorded at weekly intervals and dried to constant weight at $100^{\circ}$. The animals were weighed every week on the day when feed residues were recorded.

The lambs used in the digestibility and $\mathrm{N}$ balance trials were kept in metabolic cages for 2 weeks, during which urine and faeces were collected for the last $8 \mathrm{~d}$.

Expt 2. The three sheep were kept in individual pens and were fed ad lib. on dried grass. New feed was introduced twice daily at 09.00 and 17.00 hours. Each sheep consumed about $\mathrm{I} \cdot 25-\mathrm{I} \cdot 50 \mathrm{~kg} / \mathrm{d}$. Five bags were incubated together in the rumen of each sheep (within $0.5 \mathrm{~h}$ after the morning feeding). One bag was removed after 9, 12, I5, 18 and $24 \mathrm{~h}$ in the case of the two barleys, and after 6, I2, I 8, 24 and $36 \mathrm{~h}$ for maize. Each cereal diet was tested twice. Since it was found necessary for a complete description of the dis- 
Table 1. The effect of urea supplementation of a high-protein barley on dry matter (DM) intake, live weight gain and feed conversion ratio by early weaned lambs

(Each value is the mean of six observations*)

$\begin{array}{ccccc}\begin{array}{c}\text { Urea level } \\ \text { (g/kg diet) }\end{array} & \begin{array}{c}\text { Dietary } \\ \text { N content } \\ (\mathrm{g} / \mathrm{kg} \mathrm{DM})\end{array} & \begin{array}{c}\text { Feed intake/d } \\ \left(\mathrm{g} \mathrm{DM} / \mathrm{kg} \mathrm{W}^{0 \cdot 75}\right)\end{array} & \begin{array}{c}\text { Live weight } \\ \text { gain }(\mathrm{g} / \mathrm{d})\end{array} & \begin{array}{c}\text { Feed } \\ \text { conversion ratio } \\ \text { (g DM/g gain) }\end{array} \\ 0 & 21 \cdot 4 & 65 \cdot 5 & 171 & 4.03 \\ 6 & 24 \cdot 4 & 70.8 & 195 & 4.09 \\ 12 & 27 \cdot 3 & 79 \cdot \mathrm{I} & 259 & 3.46 \\ 18 & 31 \cdot 4 & 80 \cdot 2 & 256 & 3.61 \\ \text { SE of means } & - & 2.9 & 16 & 0.36\end{array}$

* Including some missing values (see below).

Table 2. The effect of urea supplementation of a high protein barley diet on digestibility of dry matter (DM) and organic matter (OM) and on the nitrogen balance by early weaned lambs

(Each value is the mean of three observations)

\begin{tabular}{|c|c|c|c|c|c|c|}
\hline \multirow{2}{*}{$\begin{array}{l}\text { Urea level } \\
\text { (g/kg diet) }\end{array}$} & \multicolumn{2}{|c|}{ Digestibility $(\mathrm{g} / \mathrm{kg})$} & \multicolumn{3}{|c|}{$N(g / d)$} & \multirow{2}{*}{$\begin{array}{c}\text { Retained } \\
\mathrm{N}(\mathrm{g} \mathrm{N} / \mathrm{kg} \\
\text { digestible oM } \\
\text { consumed) }\end{array}$} \\
\hline & $\mathrm{DM}$ & OM & Feed & Faeces & Urine & \\
\hline 0 & 789 & 803 & $16 \cdot 8$ & $5 \cdot 8$ & 5.9 & $8 \cdot 5$ \\
\hline 6 & 797 & 812 & $22 \cdot 4$ & $6 \cdot 2$ & $9 \cdot 6$ & 9.0 \\
\hline 12 & 795 & 810 & $26 \cdot 8$ & $6 \cdot 7$ & $12 \cdot 4$ & 10.0 \\
\hline 18 & 772 & 795 & $26 \cdot 0$ & $7 \cdot 3$ & $12 \cdot 3$ & 9.7 \\
\hline SE of means & 7 & 7 & $3 \cdot 3$ & $\mathbf{I} \cdot \mathbf{I}$ & $I \cdot 6$ & 0.14 \\
\hline
\end{tabular}

appearance to withdraw samples also at $\mathrm{r} \cdot 5,3$ and $6 \mathrm{~h}$ in the experiments with barley, further bags were incubated on a different day and removed after these intervals.

The disappearance of DM was determined for individual bags. The two bags from the same diet and incubation time of each sheep were bulked for measurement of $\mathrm{N}$ disappearance. Starch disappearance was measured in the bulked contents of all six bags (three sheep and $2 \mathrm{~d}$ ) incubated for the same period.

\section{Analytical methods}

All $\mathrm{N}$ determinations were carried out using the automated Kjeldhal method of Davidson, Mathieson \& Boyne (1970). DM was determined by drying to constant weight at $100^{\circ}$ in Expt I and at $60^{\circ}$ in Expt 2. The samples were ashed to constant weight in an electrically heated muffle furnace at $550^{\circ}$. Starch was determined as $\alpha$-linked glucose polymers by the method of MacRae \& Armstrong (I968). The results from each diet used in Expt I were subjected to analysis of variance, and the significance of linear and quadratic components of trends was tested.

\section{RESULTS}

\section{Expt I}

Of the seventy-two lambs involved, six did not complete the experiment and missing plots were calculated according to Snedecor \& Cochran (1967). Two of them died from pulpy kidney disease on the HPB diet. Four lambs, two receiving the control treatment on diet HPB, one on the control diet LPB and one on the LPB diet containing $24 \mathrm{~g}$ urea $/ \mathrm{kg}$ diet did not eat, and were eventually taken off the experiment. 
Table 3. The effect of urea supplementation of a low-protein barley on dry matter (DM) intake, live weight gain and feed conversion ratio by early weaned lambs

(Each value is the mean of six observations*)

$\begin{array}{ccccc}\begin{array}{c}\text { Urea level } \\ \text { (g/kg diet) }\end{array} & \begin{array}{c}\text { Dietary } \\ \text { N content } \\ (\mathrm{g} / \mathrm{kg} \mathrm{DM})\end{array} & \begin{array}{c}\text { Feed intake/d } \\ \left(\mathrm{g} \mathrm{DM} / \mathrm{kg} \mathrm{W}^{0.75}\right)\end{array} & \begin{array}{c}\text { Live } \\ \text { weight gain } \\ (\mathrm{g} / \mathrm{d})\end{array} & \begin{array}{c}\text { Feed } \\ \text { conversion ratio } \\ (\mathrm{g} \text { DM } / \mathrm{g} \text { gain) }\end{array} \\ 0 & 16 \cdot 7 & 54 \cdot \mathrm{I} & 87 & 5.08 \\ 8 & 21 \cdot 2 & 71 \cdot 7 & 200 & 3.62 \\ 16 & 24 \cdot 7 & 75.9 & 216 & 3.59 \\ 24 & 28 \cdot 7 & 76.5 & 225 & 3.38 \\ \text { SE of means } & - & 2 \cdot 9 & 17 & 0.16 \\ & \text { * Including some missing values (see p. 339). }\end{array}$

Table 4. The effect of urea supplementation of a low-protein barley on digestibility of dry matter (DM) and organic matter (ОM) and nitrogen balance in early weaned lambs

(Each value is the mean of three observations)

\begin{tabular}{|c|c|c|c|c|c|c|}
\hline \multirow{2}{*}{$\begin{array}{l}\text { Urea level } \\
\text { (g/kg diet) }\end{array}$} & \multicolumn{2}{|c|}{ Digestibility $(\mathrm{g} / \mathrm{kg})$} & \multicolumn{3}{|c|}{$N(g / d)$} & \multirow{2}{*}{$\begin{array}{c}\mathrm{N} \text { retention } \\
(\mathrm{g} / \mathrm{kg} \\
\text { digestible oM } \\
\text { consumed) }\end{array}$} \\
\hline & DM & OM & Feed & Faeces & Urine & \\
\hline $\begin{array}{r}0 \\
8 \\
16 \\
24\end{array}$ & $\begin{array}{l}747 \\
788 \\
809 \\
809\end{array}$ & $\begin{array}{l}761 \\
804 \\
824 \\
823\end{array}$ & $\begin{array}{l}10 \cdot 0 \\
17 \cdot 2 \\
22 \cdot 9 \\
27 \cdot 8\end{array}$ & $\begin{array}{l}3 \cdot 9 \\
4 \cdot 9 \\
6 \cdot 1 \\
6 \cdot 0\end{array}$ & $\begin{array}{r}3 \cdot 6 \\
6 \cdot 5 \\
9 \cdot 7 \\
15 \cdot 3\end{array}$ & $\begin{array}{l}5 \cdot 8 \\
9 \cdot 0 \\
9 \cdot 2 \\
8 \cdot 2\end{array}$ \\
\hline SE of means & 20 & 20 & $I \cdot 6$ & 0.6 & 0.6 & 0.8 \\
\hline
\end{tabular}

Table 5. The effect of urea supplementation of a maize diet on dry matter (DM) intake, live weight gain and feed conversion ratio by early weaned lambs

(Each value is the mean of six observations)

\begin{tabular}{|c|c|c|c|c|}
\hline $\begin{array}{l}\text { Urea level } \\
\text { ( } \mathrm{g} / \mathrm{kg} \text { diet) }\end{array}$ & $\begin{array}{l}\text { Dietary } \\
\text { N content } \\
\text { (g/kg DM) }\end{array}$ & $\begin{array}{l}\text { Feed intake/d } \\
\left(\mathrm{g} / \mathrm{kg} \mathrm{W}^{0.75}\right)\end{array}$ & $\begin{array}{l}\text { Live } \\
\text { weight gain } \\
(\mathrm{g} / \mathrm{d})\end{array}$ & $\begin{array}{c}\text { Feed } \\
\text { conversion ratio } \\
(\mathrm{g} \text { DM } / \mathrm{g} \text { gain })\end{array}$ \\
\hline 0 & 15.4 & 63.7 & 136 & $4 \cdot 9 \mathrm{I}$ \\
\hline 7 & $19 \cdot 4$ & $77 \cdot 4$ & 300 & $2 \cdot 95$ \\
\hline I4 & $22 \cdot 5$ & $81 \cdot 0$ & 282 & 3.23 \\
\hline $2 \mathrm{I}$ & $26 \cdot 1$ & $78 \cdot 5$ & $32 \mathrm{I}$ & $2 \cdot 82$ \\
\hline $\mathrm{SE}$ of means & - & $2 \cdot 6$ & 25 & $0.3 I$ \\
\hline
\end{tabular}

High-protein barley. The results from the experiment with HPB are given in Table I. The inclusion of urea resulted in significant linear increases in feed intake and live weight gain $(P<0.01)$. The last increment of urea appeared to have no effect, although the quadratic trend was not significant. Differences in food conversion ratio were not significant.

The digestibility of DM and OM, and data on $\mathrm{N}$ balance are given in Table 2.

Urea supplementation had no apparent effect on digestibility of DM and OM. There were no significant changes in faecal $\mathrm{N}$. Urinary $\mathrm{N}$ was increased linearly $(P<0.05)$. $\mathrm{N}$ retention expressed per $\mathrm{kg}$ digestible OM (DOM) intake was significantly increased. Both the linear $(P<0.001)$ and the quadratic components of the trends $(P<0.05)$ were significant, there being a levelling off in response to the higher level of supplementation. 
Table 6. The effect of urea supplementation of a maize diet on digestibility of dry matter (DM) and organic matter (OM) and of $N$ balance by early weaned lambs

(Each value is the mean of three observations)

\begin{tabular}{|c|c|c|c|c|c|c|}
\hline \multirow{2}{*}{$\begin{array}{l}\text { Urea level } \\
\text { (g/kg diet) }\end{array}$} & \multicolumn{2}{|c|}{ Digestibility $(\mathrm{g} / \mathrm{kg})$} & \multicolumn{3}{|c|}{$N(g / d)$} & \multirow{2}{*}{$\begin{array}{l}N \text { retention } \\
\text { (g/ } / \mathrm{kg} \text { digestible } \\
\text { oM consumed })\end{array}$} \\
\hline & DM & ом & Feed & Faeces & Urine & \\
\hline $\begin{array}{r}0 \\
7 \\
14 \\
21\end{array}$ & $\begin{array}{l}802 \\
869 \\
882 \\
870\end{array}$ & $\begin{array}{l}817 \\
882 \\
893 \\
882\end{array}$ & $\begin{array}{r}9 \cdot 6 \\
20 \cdot 3 \\
26 \cdot 3 \\
28 \cdot 3\end{array}$ & $\begin{array}{l}3 \cdot 3 \\
5 \cdot 3 \\
5 \cdot 1 \\
5 \cdot 4\end{array}$ & $\begin{array}{r}3 \cdot 7 \\
6 \cdot 3 \\
12 \cdot 3 \\
14.7\end{array}$ & $\begin{array}{r}5.4 \\
10.0 \\
8.9 \\
8.8\end{array}$ \\
\hline SE of means & 12 & I I & $2 \cdot 0$ & 0.7 & 0.8 & 0.3 \\
\hline
\end{tabular}

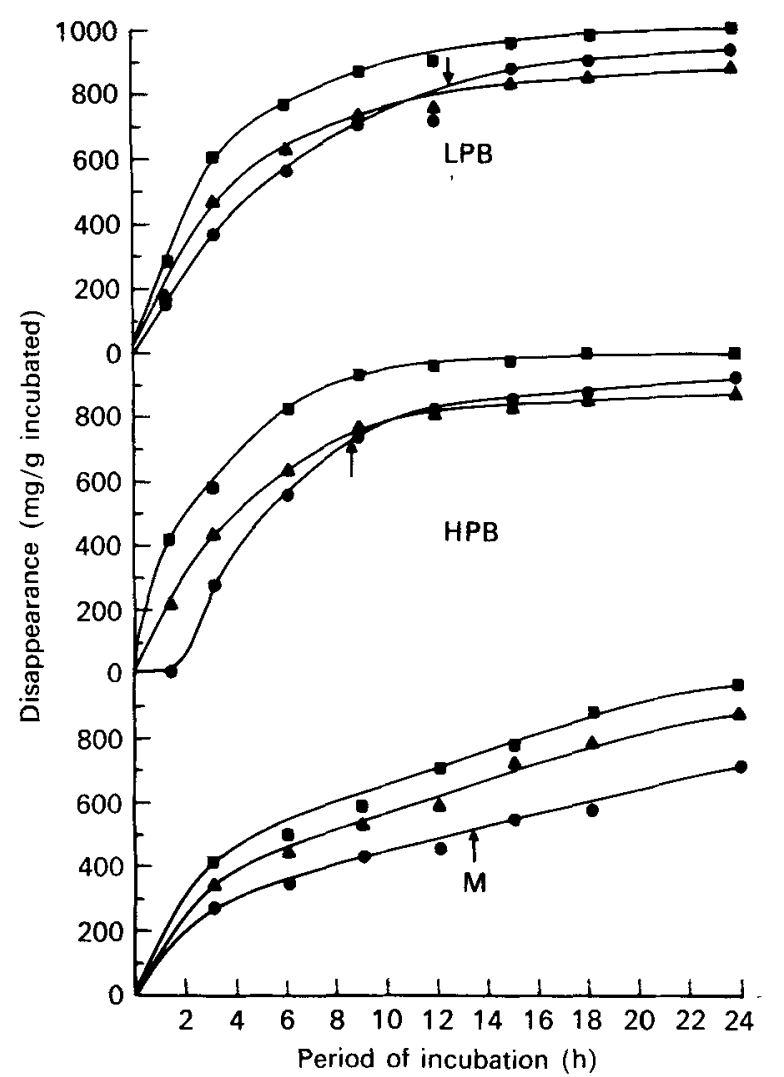

Fig. I. Disappearance of nitrogen $(\Theta)$, starch $(\square)$ and dry matter $(\Lambda)$ from polyester bags containing low-protein barley (LPB), high-protein barley (HPB) and maize (M) suspended in the rumen of sheep eating dried grass ( $a d l i b$.). The arrows indicate the estimated extent of protein degradation in the rumen.

Low-protein barley. Feed intake and utilization are given in Table 3. Urea supplementation increased feed intake, live weight gain and improved the feed conversion ratio. The response levelled off at the higher levels of supplementation. This is shown by the fact that both the linear and quadratic components were significant for feed intake $(P<0.001, P<0.05)$, live weight gain $(P<0.0 \mathrm{I}, P<0.01)$ and feed conversion ratio $(P<0.00 \mathrm{I}, P<0.0 \mathrm{I})$. 
The digestibility and $\mathrm{N}$ balance results are shown in Table 4. The increase in DM and $\mathrm{OM}$ digestibilities due to urea supplementation did not reach significance $(P>0.05)$, although they were about $60 \mathrm{~g} / \mathrm{kg}$. Faecal $\mathrm{N}$ excretion increased linearly with urea supplementation $(P<0.05)$, as did urinary $\mathrm{N}(P<0.00 \mathrm{I})$. $\mathrm{N}$ retained $/ \mathrm{kg}$ DOM intake was significantly different between urea levels 0 and $16 \mathrm{~g} / \mathrm{kg}(P<0.05)$. There were no significant quadratic trends.

Maize. Values for feed intake and utilization are given in Table 5. The increases in feed intake, live weight gain and feed conversion ratio as a result of urea supplementation levelled off at higher concentrations. Both the linear $(P<0.00 \mathrm{I})$ and quadratic $(P<0.05)$ components of these trends were significant.

Digestibility of both DM and OM increased with urea supplementation in a manner similar to feed intake (Table 6). Both the linear and the quadratic components were significant $(P<0.05)$. The increase in faecal $\mathrm{N}$ was not significant but urinary $\mathrm{N}$ increased linearly with urea supplementation $(P<0.00 \mathrm{I})$. $\mathrm{N}$ retention $/ \mathrm{kg}$ DOM also increased. Both the linear and the quadratic components of the trends were significant $(P<0.01)$.

\section{Expt 2}

The results of Expt 2 are presented in Fig. I, where the disappearance of DM, N and starch have been plotted against time of incubation. Each value for DM disappearance is the mean of six observations. The approximate SE of the means were $2.0 \mathrm{~g} / \mathrm{IOO} \mathrm{g}$ for the disappearance of $D M$ and 2.4 for $N$. For instance, the mean values at $1.5 \mathrm{~h}$ of incubation were $\mathrm{I} \cdot 3$ and $13.9 \mathrm{~g} / \mathrm{IOO} \mathrm{g} \mathrm{N}$ for HPB and LPB respectively and this difference was highly significant $(P<0.001)$.

\section{DISCUSSION}

\section{Effect on feed intake and utilization}

The increases in $\mathrm{N}$ content of all the experimental diets due to urea addition indicated that all the urea supplement, containing $450 \mathrm{~g} \mathrm{~N} / \mathrm{kg}$ was effectively absorbed by the grains.

Although sulphur was not determined in the experimental diets, it was assumed that the addition of $4 \mathrm{~g}$ anhydrous $\mathrm{Na}_{2} \mathrm{SO}_{4} / \mathrm{kg}$ diet would give sufficient $\mathrm{S}$ for the microbial requirement (see Hume \& Bird, 1970).

The low voluntary feed intake and poor performance of the lambs receiving the basal diets which were not supplemented with urea could not be attributed to the poor $\mathrm{N}$ status of the animals (Egan, 1965; Egan \& Moir, 1965), since lambs of similar status given an unsupplemented barley diet $(12.7 \%$ crude protein $(\mathrm{N} \times 6.25))$ did not increase $\mathrm{N}$ retention in response to a protein supplement given post-ruminally (Mehrez, 1976).

The improvement in voluntary feed intake and growth rate associated with the inclusion of urea in the diets are no doubt due to increases in the rate of digestion in the rumen, Balch \& Campling (1962) and Ørskov et al. (1972) recorded increases in the percentage of OM digested in the rumen when urea was added. An increase in extent of rumen fermentation caused by the increased rate of microbial degradation of substrate would probably increase microbial protein synthesis. Although microbial protein synthesis was not measured in this study, it is possible that the amount of microbial protein produced per unit substrate fermented was not increased by urea (Ørskov et al. 1972), since the lowest $\mathrm{NH}_{3}$ concentrations recorded for lambs given similar diets were about $10 \mathrm{mg} / \mathrm{I00} \mathrm{ml}$ (Mehrez, 1976) and well above the $5 \mathrm{mg} / 100 \mathrm{ml}$ considered by Satter \& Slyter (1974) and Allison (1970) to be sufficient for maximum microbial synthesis. Supplementation with urea would certainly accelerate the rate at which substrate was fermented which was convincingly demonstrated 
Table 7. Prediction of urea supplementation required for the three diets by different systems compared with amounts experimentally determined

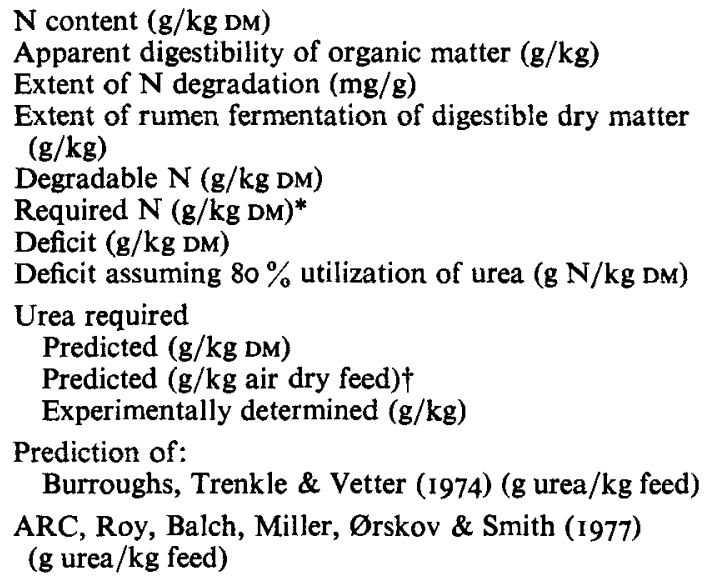

DM, dry matter. * Assuming $25 \mathrm{~g} / \mathrm{kg} \mathrm{DOM.} \quad$ * Assuming $850 \mathrm{~g} \mathrm{DM} / \mathrm{kg}$.

$\begin{array}{ccc}\begin{array}{c}\text { High-protein } \\ \text { barley }\end{array} & \begin{array}{c}\text { Low-protein } \\ \text { barley }\end{array} & \text { Maize } \\ 21.4 & 16.7 & 15.4 \\ 810 & 820 & 890 \\ 686 & 816 & 536 \\ 895 & 958 & 827 \\ 14.7 & 13.6 & 8.3 \\ 18.0 & 19.6 & 18.3 \\ 3.3 & 6.0 & 10.0 \\ 4.1 & 7.5 & 12.5 \\ & & \\ 9.1 & 16.7 & 27.8 \\ 7.7 & 14.2 & 23.6 \\ 7-11 & 9-15 & 7-14 \\ -3.4 & & \\ 2.6 & 4.5 & 10.8\end{array}$

by Mehrez, Ørskov \& McDonald (1977) with similar diets. It is not possible from the present work to assess whether, or to what extent, the proportion of dietary protein escaping rumen degradation varied between treatments.

The improvements in lamb performance can probably be explained by the increased voluntary feed intake, together with increases in extent of rumen fermentation and microbial protein synthesis associated with the inclusion of urea in the basal diets. If this is so, these results illustrate the importance of satisfying the microbial need for $\mathrm{N}$ if maximal feed intake and digestion are to be achieved. It should be pointed out that the early-weaned lambs were used because it is well known that barley supplemented with urea alone does not provide sufficient protein in the early stages of growth. Even at the optimum level of urea the protein needs of the host animals would not have been met (Ørskov et al. 1972; Ørskov, Fraser, McDonald \& Smart, 1974).

\section{Effect of protein degradation}

The difference in the extent of protein degradation between the two barleys can help to explain why $N$ was found to be limiting the rate of microbial digestion on the HPB. On the whole, except for the early period of incubation of HPB, the $\mathrm{N}$ and DM disappearance curves followed a very similar pattern (see Fig. I). The reason for the differences in degradation is not known and probably not related to the protein concentration per se. It may be associated with the method of drying the grain at harvesting. Information on this aspect was not available. The rate of disappearance of $\mathrm{N}$ from maize was slower than for barley and this applied to the starch and DM as well.

\section{Prediction of urea required to supplement different feeds}

In practice it is not possible to determine the amount of urea required for each batch of feed, and so we have attempted to predict the amount from the estimated extent of protein degradation, the estimated DM fermented in the rumen, and an average yield of microbial $\mathrm{N}$ using the principles outlined by Ørskov (1977). The predicted values were then compared 
with the amount determined experimentally and estimates using other systems, namely that proposed by Burroughs, Trenkel \& Vetter (1974), and the proposed ARC system for protein evaluation described by Roy et al. (I977).

Although the rate of starch fermentation was greater with sheep fed on grass, as in the present work, than if they were given grain diets this is not likely to influence greatly the extent of starch fermentation in the rumen (Orskov et al. I969).

The extent of protein degradation in the rumen with barley feeding was taken to be that which had disappeared by the time $93 \mathrm{~g} / \mathrm{lo0} \mathrm{g}$ starch was digested, since this is the proportion of barley starch normally digested in the rumen. For maize, the extent of protein degradation was taken to be that proportion of $\mathrm{N}$ which had disappeared when $75 \mathrm{~g} / \mathrm{r} 00 \mathrm{~g}$ starch was digested (Ørskov et al. 1969; Ørskov et al. 1972). The fractions of $\mathrm{N}$ having disappeared when the above mentioned proportions of starch had disappeared were $0.686,0.816$ and 0.536 for the HPB, LPB and maize respectively. These values are indicated in Fig. I. The proportion of digestible DM fermented in the rumen was also determined by the same means. The yield of microbial $\mathrm{N}$ per $\mathrm{kg}$ of substrate fermented was taken to be $25 \mathrm{~g}$ (Ørskov, 1977). This value was used as the requirement for degraded dietary $\mathrm{N}$ per $\mathrm{kg}$ of substrate fermented (i.e. recycling was not quantitatively taken into account).

It can be seen in Table 7 that for the two barleys the values calculated predict quite accurately the need for supplementation of urea but overestimate by far the need for supplementation of maize. The system of Burroughs et al. (1974) arrives at a value closer to that experimentally determined for maize but predicts that the HPB contains an excess of degradable $\mathrm{N}$ and it underestimates the urea required for LPB. This is due to the fact that nucleic acids- $\mathrm{N}$ are not taken to be included in microbial need for $\mathrm{N}$. Calculations by the ARC system assume that the extent of rumen fermentation of digestible organic matter is similar for all diets, being an estimate from the mean of literature values.

While the unexpectedly high requirement for urea for HPB was associated with a low estimate of degradability of protein (Table 7), it may equally have been due to the lack of synchronization between $\mathrm{N}$ degradation and energy availability. During the first $1.5 \mathrm{~h}$ of incubation, for instance, only about $\mathrm{I} \%$ of the $\mathrm{N}$ had disappeared with HPB, while about $14 \%$ of the $\mathrm{N}$ had disappeared with LPB (see Fig. I). This may imply that a deficiency of $\mathrm{N}$ which limits rate of digestion occurred only immediately after a feed had been consumed, while at other times, $\mathrm{N}$ may be in excess. This of course may depend on frequency of feeding and the amount eaten at each feed. The high urinary excretion of $\mathrm{N}$ when urea was added to HPB suggests a very low apparent net utilization of urea. On the other hand, feed intake greatly increased as a result of urea supplementation, indicating that the rate of digestion in the rumen was limiting, at least during part of the time.

The tendency to overestimate the supplementary $\mathrm{N}$ needed for the fermentation of maize, even if the lesser extent of rumen fermentation was taken into account, is difficult to explain. The principal difference between maize and barley here was the rate at which the substrate was fermented (Fig. I). If this is important, then it would suggest that there may be a greater need for urea supplementation in diets based on flaked or cooked maize since flaked maize appears to be fermented in the rumen at the same rate and to the same extent as barley (Ørskov et al. 1969).

\section{REFERENCES}

Allison, M. J. (1970). In Physiology of Digestion and Metabolism in the Ruminant, p. 456 [A. T. Phillipson, editor]. Newcastle-upon-Tyne: Oriel Press.

Balch, C. C. \& Campling, R. C. (1962). Nutr. Abst. Rev. 32, 669.

Burroughs, W., Trenkle, A. \& Vetter, R. L. (1974). Vet. Med. Small Animal Clin. 69, 713.

Davidson, J., Mathieson, J. \& Boyne, A. W. (1970). Analyst 95, I8I.

Egan, A. R. (1965). Aust. J. agric. Res. 16, $45 \mathrm{I}$. 
Egan, A. R. \& Moir, R. J. (1965). Aust. J. agric. Res. 16, 437.

Hume, I. D. \& Bird, P. R. (1970). Aust. J. agric. Res. 21, 315.

MacRae, J. C. \& Armstrong, D. G. (1968). J. Sci. Fd. Agric. 19, 578.

Mehrez, A.Z. (1976). Assessment of the nitrogen requirement for rumen fermentation in sheep. PhD Thesis, University of Aberdeen.

Mehrez, A. Z. \& Ørskov, E. R. (I977). J. agric. Sci., Camb. 88, 645.

Mehrez, A. Z., Ørskov, E. R. \& McDonald, I. (1977). Br. J. Nutr. 38, 447.

Miller, E. L. (1973). Proc. Nutr. Soc. 32, 79

Nimrick, K., Hatfield, E. E., Kaminski, J. \& Owens, F. N. (1970). J. Nutr. 100, I 301.

Orskov, E. R. (1970). In Proc. 4th Nutr. Conf. Feed Manufrs., Nottingham [D. Lewis and H. Swan, editors]. London: J. \& A. Churchill.

Ørskov, E. R. (1977). Wld. Rev. Nutr. Diet. 26, 225.

Ørskov, E. R. \& Benzie, D. (1969). Br. J. Nutr. 23, 415.

Ørskov, E. R., Fraser, C. \& Kay, R. N. B. (1969). Br.J. Nutr. 23, 217.

Orskov, E. R., Fraser, C. \& McDonald, I. (1972). Br.J. Nutr. 27, 49 I.

Ørskov, E. R., Fraser, C., McDonald, I. \& Smart, R. I. (1974). Br. J. Nutr. 3I, 89.

Orskov, E. R. \& Grubb, D. A. (1977). Anim. Feed Sci. Technol. (In the Press).

Ørskov, E. R., Smart, R. I. \& Mehrez, A. Z. (1974). J. agric. Sci., Camb. 83, 299.

Roy, J. H. B., Balch, C. C., Miller, E. L., Ørskov, E. R. \& Smith, R. H. (1977). Proc, and EAAP Symposium on Protein Metabolism and Nutrition.

Satter, L. D. \& Slyter, L. L. (1974). Br. J. Nutr. 32, 199.

Schelling, G. T. \& Hatfield, E. E. (1968). J. Nutr. 86, 319.

Snedecor, G. W. \& Cochran, W. G. (1967). Statistical Methods, 6th edn. Ames, Iowa: Iowa State University Press. 